\title{
A Social Web Based Pedagogical Strategy for Teaching Journalism in Higher Education
}

\section{Una Estrategia Pedagógica Basada en la Web Social para la Enseñanza del Periodismo en la Educación Superior}

\author{
Carla Patrão \\ CISUC, Universidade de Coimbra \\ carla@dei.uc.pt \\ António Dias de Figueiredo \\ CISUC, Universidade de Coimbra \\ adf@ dei.uc.pt
}

\begin{abstract}
Resumen
Este artículo presenta una estrategia pedagógica para la enseñanza de periodistas en la educación superior. Su principal característica es que ocurre principalmente en la web social, con los estudiantes compartiendo sus producciones periodísticas en un blog colectivo y discutiendo su trabajo en una página de Facebook. La estrategia también apunta a desarrollar el sentido de autonomía y participación democrática de los estudiantes y su conciencia de los valores y prácticas de la profesión. La estrategia es la culminación de un proyecto de investigación-acción de tres ciclos, desarrollado durante un período de cinco años, sobre cómo educar a los periodistas a través de experiencias de aprendizaje innovadoras basadas en las nuevas tecnologías. Creemos que tanto la estrategia como la investigación que condujo a ella pueden inspirar a educadores e investigadores preocupados por los desafíos de la educación en la web social.
\end{abstract}

\section{Palabras claves}

Teoría de la actividad, Educación, Periodismo, McLuhan, Web Social.

\begin{abstract}
This article presents a pedagogical strategy for the education of journalists in higher education. Its main characteristic is that it occurs mainly on the social web, with the students sharing their journalistic productions in a collective blog and discussing their work on a Facebook page. The strategy also aims at developing the sense of autonomy and democratic participation of the students and their awareness of the values and practices of the profession. The strategy is the culmination of a three-cycle action-research project, developed over a period of five years, on how to educate journalists through innovative learning experiences based on new technologies. We believe that both the strategy and the research that led to it may be inspiring to educators and researchers concerned with the challenges of education on the social web.
\end{abstract}

\section{Keywords}

Activity Theory, Education, Journalism, McLuhan, Social Web.

\section{Introduction}

This article proposes a pedagogical strategy for teaching journalism in higher education. Its most distinctive feature, when compared with other approaches for the education of journalists, is that it is based on the social web - the students develop their collective journalistic work on a shared blog and the main dialogic component of the course takes place on a Facebook page created for the purpose. Other major learning objectives of the strategy 
are nurturing the sense of autonomy and democratic participation of the students and developing their awareness to the values and practices of the profession. The strategy evolved as the culmination of a three-cycle action-research project on "how to educate a new generation of journalists through innovative learning experiences based on new technologies", developed over a period of five years with students of the Social Communications Course of the Superior Education School of Coimbra (ESEC).

The practice of journalism faces numerous challenges. Among them, the arduous process of entry into the profession, obscured by precarious employment, the burden of keeping up with the growing sophistication of the technology, and the flooding of the media space with increasingly shallow varieties of journalism. In spite of the core role played by journalism in democratic and developed societies, we witness its widespread struggle to adapt to the challenges of the new models, its fight for survival and its painful pursuit of sustainability. The access to information is much faster and more efficient, due to the ample accessibility to content and the diversification of means, so this might look as a promising advantage for journalists. However, the advantage applies to both the journalists and the audience, so it ends up vanishing. We also witness a monotonous homogenisation of the representations of reality: the same subjects, the same sources, the same approaches and protagonists day after day. As for the audiences, they are getting closer and closer to taking the role of the journalists: the faces of the public are becoming more and more associated to opinions, viewpoints, and criticism. We are thus being confronted with a set of factors that have a common thread, what some authors call "converging media" (Gordon, 2003; Pavlik, 2018), with varying semantics. All these questions are leading to a reconfiguration of the professional practices of the journalist in a context that it is both enabled and challenged by technology.

In Portugal, where the project that led to this strategy was developed, a journalist is exposed to all these challenges, which are felt regardless of the surrounding social and cultural factors. What the literature tells us about journalism as a profession in Portugal is that the number of professionals in the field has been declining (Gomes et al., 2011; Matos et al., 2017), or has been "adjusted", to use a recent euphemism of our lexicon. It is a profession with a high female/male ratio, which nevertheless does not propagate to the management positions. Unlike other countries, Portugal accepts journalism as an open profession: everyone who has a permanent and remunerated position in the field is officially recognised as a journalist. At any rate, the literature shows that the entry into the profession is arduous. Those who become interns in their first professional years quickly realise that the future does not hold promises of security, and this even applies to journalists who have been in the profession much longer (Graça, 2007; Rebelo, 2011). In spite of the openness of the profession, which would enable anyone to become a journalist, higher education is seen as a preferred route for the qualification of journalists (Obercom, 2017), since it reinforces the role played by higher training, provides a coherent curriculum, and guarantees the quality of its own programs. With this in mind, it seems pertinent and urgent to engage in a structured reflection on the pedagogical strategies to support the qualification of journalists in higher education.

The core of this article is made up of two parts. The first part describes the three cycles of an action-research project we developed over the course of five years, from which the proposed pedagogical strategy emerged. The second part starts by introducing two theoretical strands that support our pedagogical strategy, McLuhan's Tetrad model and Activity Theory, after which it presents the strategy itself in the form of a concise model, the PECA Model, named 
after the initials of its four dimensions: Participation, Exposure, Competence, and Awareness. The article closes with a few conclusive remarks.

\section{The action-research project}

This research presents an answer to the question of how to educate a new generation of journalists. It bears in mind that the younger generations are facing new learning and social challenges and that journalism is probably the fastest changing traditional profession of our times. It emphasizes the practice of education through innovative learning experiences that break away from the traditions of journalism education and rely heavily on the mediating potential of technology. Action-research was chosen because it fulfills the purpose of intervening in a reality with the aim of changing it for the better, while simultaneously improving the knowledge on how to do it.

\subsection{1st cycle - The prospect of Moodle}

Our first approach to the formal use of social software tools for the education of journalists was based on a popular learning management system, Moodle, in support of a project entitled e-communicate. The project started in 2005, when Moodle was being extensively diffused in the academia thanks to the curiosity of several educators who recognised in the platform an opportunity to innovate their teaching, improve the communication with their students and offer greater accessibility to academic content.

For us, it was an exploratory approach to the use of technological platforms in the education of future journalists. The enthusiasm and participation of the students of the Social Communication Course of ESEC was the main reason why we chose it as the grounds for our subsequent research. In addition to opening doors to a shared learning process within a community, the e-communicate project generated interesting guidelines for research on how technology could bring innovation to the process of teaching and learning and contribute to better prepare the future journalists for the labor market. Throughout the project, we kept track of its progress and synergies at various moments and reflected on the pedagogical prospects offered by the use of Moodle, namely to foster social learning experiences (Patrão, 2006) and outline its institutional implementation (Patrão \& Soeiro, 2009a, 2009b).

Among the actions where we used Moodle to support b-learning and extend the curricular activities outside the classroom, the discipline of Cyberculture provided the most interesting results and laid the foundations for the research we developed from there. We observed that the students were attracted from the outset due to the novelty factor provided by the technology and the flexibility it offered for self-paced learning and time management. We started by proposing activities involving thematic discussions and group projects of content publishing for which the students were invited to establish themes, formats, priorities, and responsibilities. They were thus presented with the opportunity to practice journalism in cyberspace while improving their skills and autonomy in a participative and engaged way.

After this favourable learning experience with the Social Communication students of the ESEC, we were left with a set of indicators pointing to the fundamental idea that this educational format resulted in student groups that were motivated and engaged in extensive collaborative activities that promoted the practice of personal and professional journalism skills. With these indicators lined up, we decided to start inquiring into the improvement of the pedagogical strategies for three fundamental activities: thematic discussion, publication 
projects, and peer evaluation. We then set out to clarify the indicators of the pedagogical experiences the students had found more distinctively positive. Finally, as the idea of digital communities started to take shape, a new question developed in our minds: would it be possible to extend the activity of the community beyond the academic context into a more professional environment? These were the findings and insights that carried us into the second action-research cycle.

\subsection{2nd cycle - The myempowermedia project}

This action-research cycle was supported by an online content management system with social networking features, the Dolphin platform. We wanted to keep focused on the close participation of the students in their initiatives, but within an environment more akin to a social network and more likely to let them express their self-determination. For this reason, we called the project myempowermedia. In this new environment, we openly adopted the principles of project-based learning, with the students building their knowledge and competencies while carrying out projects that were individually and collectively significant and included the debate of ideas, participation in activity planning, and content production (Blumenfeld et al., 1991). We also systemised and improved a peer evaluation system for the students, to facilitate their evaluation, enrich the pedagogical context, and help them develop critical thinking skills immediately applicable to their personal journalistic work and the journalistic work of their peers. We also prepared for the future evaluation of the whole learning experience, which would include the analysis of the reports of the participating students (Patrão, 2015).

The myempowermedia cycle included a project for producing a publication. It involved creating journalistic pieces, in various formats, to be published for the whole community of the course. The community would in turn assess the work carried out using a set of agreed evaluation and classification criteria. Apart from the production, publication, and evaluation activities, the students held thematic discussions in the forums of the platform on various aspects of journalism. For the whole process, the students organised themselves in groups, defined their roles and levels of responsibility, and worked autonomously within previously agreed allotted time periods and deadlines.

When we reached the stage of evaluating the whole learning experience, we received twentythree written reports resulting from the individual evaluations of the participating students. From this group of students, we invited fifteen to give semi-structured interviews. The resulting content was submitted to a detailed analysis in search of signifiers that could be organised into families and thematic units. The grouping of this content focused on the perceptions and representations of the learning experience, the community experience and the perceived roles of journalism as a profession.

From this content analysis, we concluded that the learning experience, as seen by the students, was a good approximation to the professional reality. This happened largely because the context created mobilised journalistic competences, simulated professional positions and replicated to some extent the functioning of a newsroom. In particular, the students learned how to manage feelings of pressure, responsibility, and visibility. The Internet was widely recognised as a place of opportunity for external exposure and the interactions generated within the groups were valued as important parts of the context.

A social web based pedagogical strategy for teaching journalism in higher education. Carla Patrão y António Dias de Figueiredo

Page 4 of 14 
We used a scoring rubric to assess the perception of the learning experience by the students, and they found that the use of rubrics facilitated peer learning and allowed them to improve their own work, in spite of the embarrassment and discomfort of evaluating the colleagues. Another aspect we wanted to clarify was the ability of our approach to develop a vision of journalism as a profession. We particularly wanted to check its aptitude to develop in the students a personal awareness that guided the self-assessment of their progress towards the profession, an objective at the core of our pedagogical strategy. We interpreted our data so as to differentiate between two perspectives: "being in journalism" (the practices of the profession), i.e. being directly involved in everyday professional practice; and "to be in journalism" (the values of the profession), i.e. being impartial, responsible, and objective at the service of a social function.

When we reached the end of the year, the students got their marks, and the project closed, we invited the students to continue on their own during the holidays, but the myempowermedia community, in spite of the preference it had developed in the students, had not proved to be attractive enough to grant its own sustainability. In the reflection that followed the termination of this second cycle, we decided that the adoption of closed and proprietary learning management platforms was not appealing enough and suggested the adoption of more general platforms. We also felt that it might be valuable to make sure that the work published by the students was exposed to the outside world.

\subsection{3rd cycle - The blog-Facebook combination}

Three fundamental questions guided the preparation of the third action-research cycle: firstly, we wanted to confirm the extent to which our pedagogical strategy could produce similar perceptions in a new group of students; secondly, we wanted to understand to what extent the use of the combination between a blog and a Facebook page pointing to it could lead to an improved experience; thirdly, we wanted to find out whether the prospects of a more sustainable future for the community could be improved.

In this cycle, which started in the academic year of 2010/2011, we followed the same pedagogical strategy: a publishing project and a peer review. The most visible practical effect was that the combination of Facebook with a blog immediately generated much more participation and interaction. It was interesting to notice, in this respect, the occasional "return" of some ex-students, both through comments and through their journalistic contribution to work the group was developing, which gave us an indication of their sense of belonging to the new community. On the less bright side, we noticed recurrent delays in the submission of the materials and the peer assessment of the publications, which was uneven between participants.

For data collection, we resorted again to individual interviews and content analysis. A few more questions were added to the interview script to address the more autonomous engagement of the students in the proposed tasks. We included questions on political sensibilities, democratic decisions, digital citizenship, and empowerment, which we then classified during content analysis combining them with the perception of the existence of a community experience.

To summarise the main results of this action-research cycle, we observed again a learning experience that the students considered positive, namely by valuing the increased external

A social web based pedagogical strategy for teaching journalism in higher education. Carla Patrão y António 
exposure, the familiarisation with work under pressure, and the contact with several facets of journalistic production. Once again, the students spoke of a sense of proximity to the professional reality and of having improved their competencies and professional skills. When we asked the students about the quality of the materials they had published, they expressed a split of perceptions between the work for which they were allowed to establish autonomously the time and techniques to use and the work that required them to adhere to strict schedules. Regarding the use of the peer evaluation system, we observed representations similar to those of the previous cycle. The students recognised its usefulness for learning, but felt aggrieved about the discomfort of evaluating the work of their colleagues.

In this cycle, we also perceived indicators of the existence of a community: sense of belonging, common objectives, and interaction within groups with compatible interests. The students interviewed also described the generation of group dynamics that changed their political sensibilities and their awareness about diplomacy and management decisions, which had contributed to guide the activities and orientation of the group to which they belonged. Finally, through the interviews, we confirmed that the individual cooperation and collective decision-making in shared endeavours had a positive impact on the awareness of the students about personal and collective empowerment.

\section{The Pedagogical Strategy Model}

Now empowered with the knowledge and insight gained from our three action-research cycles, we felt we could venture into the development of a pedagogical strategy that encapsulated our conclusions and responded to our original question: "how to educate a new generation of journalists through innovative learning experiences based on the new technologies". Having revisited the literature in light of the results and conclusions obtained, we retained two main theoretical strands to support our strategy: McLuhan's Tetrad Model for the analysis of media effects (Patrão \& Figueiredo, 2011) and Activity Theory, a social science theory for the description of human activities as systemic and socially situated phenomena. The result was our pedagogical strategy model, the PECA Model, named after the initials of its four dimensions: Participation, Exposure, Competence, and Awareness.

\subsection{From the global village to McLuhan's tetrad of media effects}

The path followed by our action-research project, from its initiation on the Moodle platform to a more dynamic and contemporary combination of Facebook with a blog, is in some sense similar to a journey from the concept of traditional classroom to the idea of a "global village" proposed by one of the most influential figures of communication studies, Marshal McLuhan (1962). The analogy can actually be extended to fit the parallelism between classroom and city suggested by McLuhan and his collaborators in the book City as Classroom (M. McLuhan, Hutchon, \& McLuhan, 1977). As McLuhan put it in one of his writings: "We seem to be approaching the age when we shall program the environment instead of the curriculum" (McLuhan, 2003, p. 53).

In her debate on the future of journalism education, Donica Mensing (2010) defended the idea of journalism as community building rather than industrial production, stressing the need to anchor journalism back into its democratic roots, in an era where we can take advantage of the latest ways to create, produce, and distribute news. Inspired by the ideas of James Carey (1989) and John Dewey (1927), this vision of the future of journalism places the journalist in a community and sees him/her as a reporter, editor and facilitator in a web of relationships. The education of journalists must thus take into account that journalistic production within

A social web based pedagogical strategy for teaching journalism in higher education. Carla Patrão y António Dias de Figueiredo

Page 6 of 14 
networks differs from industrial production for passive consumers. As a result, the students must learn to collaborate with the community they address and develop competences of moderation and facilitation that lets them benefit from all the opportunities this collaboration affords.

McLuhan anticipated far in advance this new world, where a new kind of journalism is needed, and his vision now helps us put it in perspective. Recalling the utopia of the "big community" proposed by John Dewey in The Public and Its Problems (1927), we may say that McLuhan's "global village" is Dewey's "big community" extended to the whole world and reinforced by the power of electronic connectedness. In this context, McLuhan's reflections on the relationship between media and society, collected in The Laws of Media (M. McLuhan \& E. McLuhan, 1988) and published posthumously by his son, is a valuable legacy. As Eric McLuhan explains in the preface of the book, this work attempted to reify Marshal McLuhan's ideas in light of Karl Popper's principles on the role of falsification in science: "It took my father nearly two full years of constant inquiry to find out 'what constitutes a scientific statement'. He asked everyone he encountered - colleagues, students, friends, associates, visitors. Finally, one evening, he found the answer in Sir Karl Popper's Objective Knowledge - that it was something stated in such a manner that it could be disproved". This became the core concern of the book - to establish for the media a set of fundamental principles that could be universally tested.

McLuhan's four principles, his Laws of the Media, were formulated as questions:

- What does the artefact enhance or intensify or make possible or accelerate?

- If some aspect of a situation is enlarged or enhanced, what is pushed aside or obsolesced by the new 'organ'?

- What recurrence or retrieval of earlier actions and services is brought into play simultaneously by the new form? What older, previously obsolesced ground is brought back and inheres in the new form?

- When pushed to the limits of its potential, the new form will tend to "overheat" and revert to its original characteristics. What is the reversal potential of the new form?

These fundamental questions were then put together in a Tetrad Model that, the authors found out, "applied to more than what is conventionally called media: they were applicable to the products of all human endeavor, and also to the endeavor itself" (p. ix), confirming an essential tie between artefact and word, speech and artefact. This Tetrad Model offers a holistic interpretation of space and context that is ideal for the exploration of signifiers in the reflexivity between new and old, anterior and posterior, before and after. Inspired by Gestalt psychology, the authors saw the Tetrad Model as the aggregation of the functions of the cerebral hemispheres that let us visually separate the prominent figure from the background figure, the subject from context.

To reflect further on the conclusions of our action-research project, we applied the Tetrad Model to the successive technological platform options of our project. As these options represented changes in the means of technological mediation, we could identify what was enhanced, obsoleted, brought back from past traditions and reversed when pushed to the limits of its potential. In the first action-research cycle, the use of Moodle as a learning management platform enhanced the access to content and its distribution within a reference group, as well as the communication between the actors involved in the process of teaching

A social web based pedagogical strategy for teaching journalism in higher education. Carla Patrão y António Dias de Figueiredo

Page 7 of 14 
and learning. The importance of communication based on verbal and written discourse was brought back, thanks to the forum tools and synchronous discussions afforded by Moodle. What became partly obsolete were the canonical strategies of teaching, which attempted to create a simultaneous channel for the maintenance of the academic activities. In general, the Moodle cycle represented a turning point that liberated the classroom from the constraints of space and time. Considering its limitations in generating interactions, despite its independence from space and time, when the technological medium is pushed to the limits of its potential, the learning experience may reverse into a closed bureaucracy of content exchange and publication in forums - a village isolated from the world. This analysis is summarised in the column "Cycle one: Moodle" of Table 1, which illustrates the application of McLuhan's tetrad to our three action-research cycles.

Table 1 - The application of McLuhan's tetrad to our the action-research cycles

\begin{tabular}{|c|c|c|c|c|}
\hline \multicolumn{2}{|c|}{$\begin{array}{l}\text { Tetrad Dimensions } \\
\text { of the Media }\end{array}$} & Cycle one: Moodle & Cycle two: Dolphin & $\begin{array}{l}\text { Cycle three: Blog/ } \\
\text { Facebook }\end{array}$ \\
\hline \multirow[t]{3}{*}{ Figure } & Enhance & Communication & Sense of community & Visibility \\
\hline & & Content distribution & & \\
\hline & Retrieve & $\begin{array}{l}\text { Nexus of written } \\
\text { discourse }\end{array}$ & $\begin{array}{l}\text { The Agora } \\
\text { democracy context }\end{array}$ & Social participation \\
\hline \multirow[t]{3}{*}{ Ground } & $\begin{array}{l}\text { Make } \\
\text { obsolete }\end{array}$ & $\begin{array}{l}\text { Time constraints of } \\
\text { classroom }\end{array}$ & $\begin{array}{l}\text { Dispersion of social } \\
\text { interaction tools }\end{array}$ & $\begin{array}{l}\text { Idea of school as a } \\
\text { closed space }\end{array}$ \\
\hline & & & $\begin{array}{l}\text { The academic bond } \\
\text { is challenged }\end{array}$ & \\
\hline & Reverse & $\begin{array}{l}\text { Closed virtual } \\
\text { bureaucracy }\end{array}$ & $\begin{array}{l}\text { Collaboration } \\
\text { without mechanisms } \\
\text { to pace and control it }\end{array}$ & $\begin{array}{l}\text { Learning through } \\
\text { genuine practice }\end{array}$ \\
\hline
\end{tabular}

With the Dolphin platform (Table 1, column "Cycle two: Dolphin"), the second actionresearch cycle enhanced a sense of community and the call for a more refined sense of citizenship - demonstrated, for example, by the students' acceptance of being evaluated by their peers, their proposed revisions of journalistic productions, and their negotiation of common strategies for the editorial orientation of their online publications. To some extent, these examples were a recovered image of the Agora of Ancient Greece brought back as the symbolic representation of a sphere of community influence. The Dolphin platform had succeeded in making available the Internet tools of social interaction, such as chats, forums, blogs and event schedules. This generated the obsolescence of the traditional visions of the content management platforms used for distance learning, more focused on content than on interaction and more oriented towards the management and delivery of sessions than to the creation of richer learning environments. Notwithstanding, the low external visibility of the work produced by the community persisted in this option, particularly in the inability of the platform to provide exposure and attract outside parties to contribute to the development and motivation of the students. Pushed to the limits of its potential, the Dolphin environment might reverse into chaotic forms of collaboration and interaction that could result from its lack of control mechanisms and might fail in transforming cooperation into productive links with the outside world. 
Some of the limitations of the previous cycles were overcome in the third action-research cycle, where a blog served as a collective portfolio that was, in turn, discussed in a Facebook group created for the purpose. The exposure of the work produced by the students was higher than it had been in the previous cycles, as demonstrated by the number of people who joined the group. The broader social participation, with the students interacting with older students, professionals and external Facebook "friends", generated much more intensive interaction. In this way, the third cycle enhanced the exposure of the students and their work (last column of Table 1), but recovered to some extent the ideal of social participation in a classroom, typical of traditional closed environments, although this new "classroom" did away without the traditional closure of the students in fenced spaces and encouraged them to interact and collaborate with the external world. Pushed to the limit, this solution might degenerate into an environment too informal to be of use for formal teaching and learning. However, the cooperation between students, professionals, and other interested parties could ideally revert into a new renaissance of the training of traditional journalists, which happened, in the past, in the context of daily practice under the supervision of more experienced peers.

With the help of the Tetrad Model, we were able to gain further insight into the modalities of student participation and the community representations as enabled and reinforced by the mediating technologies. The reaction of the students to the external exposure of their work, in the third cycle of the project, deserves special attention because it brought to our attention a phenomenon that is well known but little studied: the role of the audience in the quality of any public performance. Just as professional actors and communicators tend to perform better when they have a supportive public, the students also tend to perform better when they have an audience other than the teacher. We are currently researching this phenomenon further, in order to understand it better from the psychological, sociological, and pedagogical points of view.

\section{Activity theory}

Primarily based on the work of Lev Vygotsky, activity theory aims to understand the unity between consciousness and activity. Its basic principles include: "object-orientedness, the hierarchical structure of activity, internalization/externalization, mediation, and functional organs" (Nardi, 1996, p.4). It groups principles particularly suited to the analysis of activities where human beings relate with (and through) tools. In its most basic form, it is described by a triangular model where subject, object, and mediating artefacts (tools) are interconnected and oriented toward an outcome. Engeström (1987) argued that this basic model does not express the relationship between the individual and the environment (the community) and proposed two new types of relationships, subject-community and community-object, as shown in Figure 1.

The unity between consciousness and activity and the social nature of the human mind are two core principles set forward by Leontiev and Vygotsky for their theoretical model. The first principle states that consciousness develops in the context of the relationship between subject and object; the second principle establishes that society and culture are forces that influence consciousness (Kaptelinin \& Nardi, 2006, p. 66). This notion that consciousness results from action aligns with the pedagogical options we have tested in our action-research cycles. Through organised activities, we intentionally encouraged in the students a kind of awareness that fostered their autonomy and the ease of their subsequent transition to the labor

A social web based pedagogical strategy for teaching journalism in higher education. Carla Patrão y António Dias de Figueiredo

Page 9 of 14 
market. In practice, we used what Lektorsky (2009), revisiting the main components of Engeström's model, described as reflective mediation, a way of introducing change in collective activity.

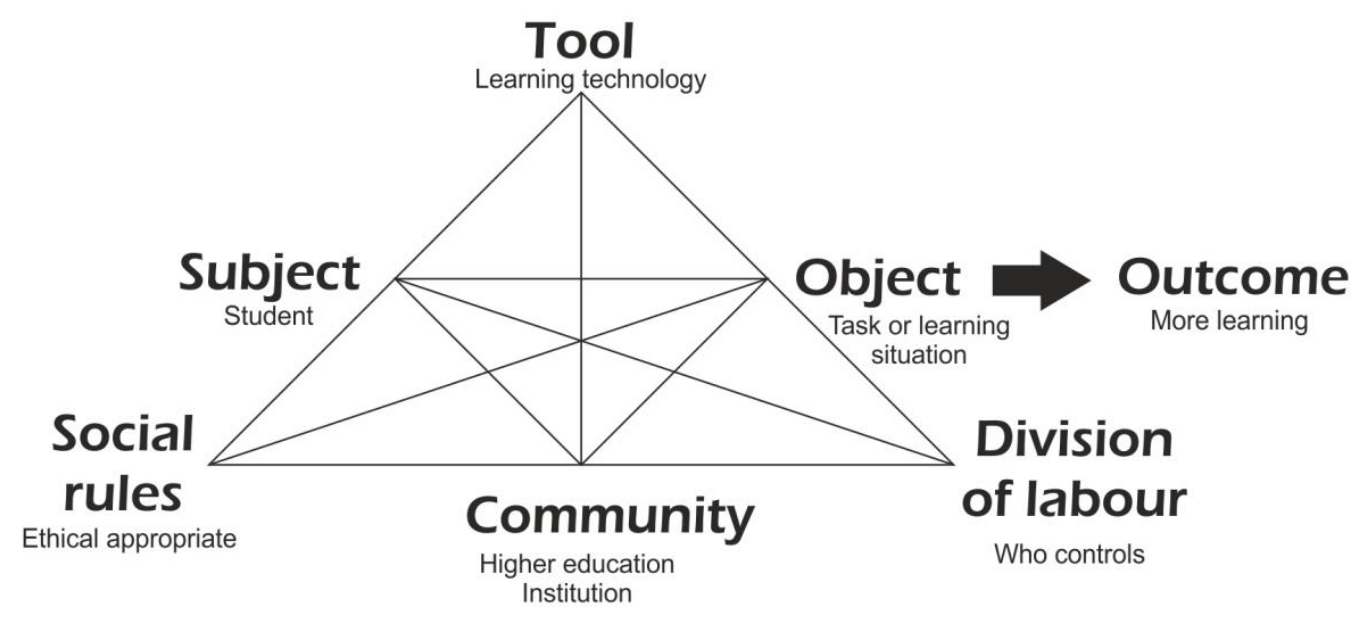

Figure 1 - Activity Theory model applied to higher education (Scanlon \& Issroff, 2005)

\section{A pedagogical strategy: the PECA model}

Summing up the dimensions of our action-research trajectory, we now propose the model for a pedagogical strategy that responds to the question of "how to educate a new generation of journalists through innovative learning experiences based on new technologies". As shown in Figure 2, the PECA model consists of four dimensions: participation and exposure, competence and awareness. Concisely, we can say that the PECA model departs from a relationship between participation and exposure to generate competence and awareness.

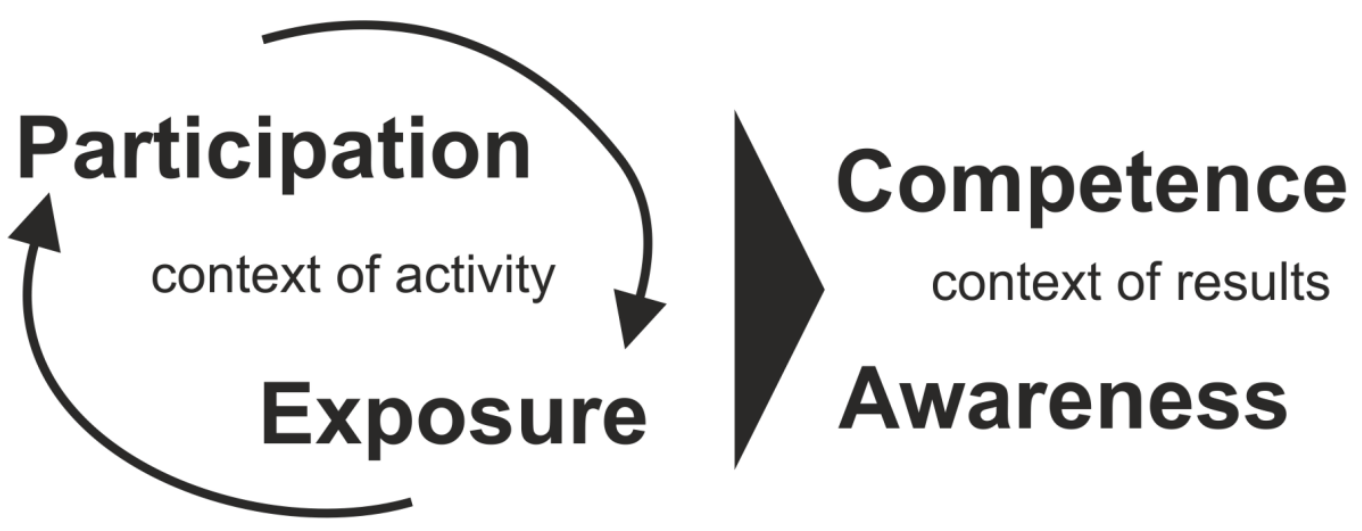

Figure 2 - Visual representation of the PECA model

The dimensions of participation and exposure occur within the activity itself. They are described by two arrows that represent a relationship of dynamic mutual dependence: participation leads to exposure and exposure leads to participation. Participation includes all the initiatives and opportunities undertaken to complete a proposed common project. In our case, the common project was the journalistic production agreed with the students, satisfying a set of agreed requirements and observing the rights and duties of all the interested parties. In 
order to establish a rationale of balance between individual work and collective effort, we organised the students in small groups. This organisation requires each group to define, itself, the strategies, directions, deadlines, and tasks. Successful participation requires valuing the initiatives, opinions, and expectations of the students, while observing the established norms. This phase of participation also includes the exploration of a peer evaluation system opened to the questioning of the objects produced. The curricular activities, which are organised to support the publication project, include thematic discussions as a way of approaching the concepts and ideas that are integral to the course agenda.

The dimension of exposure gives the journalistic project its genuine reason of existence. Without exposure, participation would have been an empty pedagogical exercise. Exposure is the powerful motivational factor that engages the students into participation and encourages them to put as much effort as they can into the quality of their products. It is also the coronation of the social function of any journalistic project.

The dynamic, synergetic, relationship between participation and exposure is, in turn, the engine that develops competence and awareness. This is not, in practice, a linear process. The anticipation of successful exposure built into the strategy plays an important role in amplifying the dialectics between participation and exposure and in developing the feedback loops of competence building and incremental awareness. This is visible in the reports that result from the student interviews, namely when they address the extent to which the learning experiences approximate their expectations about their role as future professionals.

\section{Conclusions}

The PECA model summarises the dimensions of a pedagogical strategy that emerged from our attempt to answer the question of how to educate a new generation of journalists through innovative learning experiences based on new technologies. The strategy distinguishes two contexts: the context of the activity and the context of the result. The context of the activity, built on a mutually constitutive and dynamic relationship between participation and exposure, provides opportunities for the development of a journalistic publication project that is appropriated by the students and exposed to the critical eye of their peers and the attention of other interested parties. The context of the result points to the accumulation of competence and professional know-how by the future journalists and to the development of their awareness about the path to follow towards the profession.

The key difference of the PECA strategy when compared to traditional educational strategies is that the students respond primarily to a genuine outside audience, instead of responding to the teacher. This makes the PECA learning environment similar to the environments of professional actors and public communicators, whose performance improves when the public is supportive - a phenomenon well known in the performing arts, but still largely unexplored in educational literature. This positive influence of the existence of a genuine audience on the signs of authenticity of the work produced by the students, their motivation, and their metacognitive development was one of the most unexpected conclusions of our research, which we intend to explore in depth in future research cycles.

This model synthesises a set of practices identified as pertinent in the context of our actionresearch project. Its validity is, thus, confined to the context of our experience. We believe, however, that both the model and the research approach that led to it can be inspirational for

A social web based pedagogical strategy for teaching journalism in higher education. Carla Patrão y António 
the educators and researchers concerned with the challenges of education on the social web. We also believe that McLuhan's Tetrad Model and the principles of Activity Theory, as we described them in this article, may be helpful for the theoretical support of identical projects. In his 1971 Convocation Address, McLuhan claimed that "The university and school of the future must be a means of total community participation, not in the consumption of available knowledge, but in the creation of completely unavailable insights" (McLuhan, 1971). We hope that the pedagogical strategy we have just proposed can be a contribution to that ideal.

\section{Financing}

This research has not received any specific subsidies from funding agencies in the public, commercial or non-profit sectors.

Presentación del manuscrito: 31 de enero de 2018

Fecha de aprobación: 23 de marzo de 2018

Fecha de publicación: 31 de marzo de 2018

Patrão, C. y Figueiredo, A. D. (2018). Una Estrategia Pedagógica Basada en la Web Social para la Enseñanza del Periodismo en la Educación Superior. RED. Revista de Educación a Distancia. 57(8). 31 de marzo de 2018. Consultado el (dd/mm/aa) en http://www.um.es/ead/red/57

\section{References}

About Moodle: philosophy. (2014). Available at http://docs.moodle.org/27/en/Philosophy.

Blumenfeld, P. C., Soloway, E., Marx, R. W., Krajcik, J. S., Guzdia, M., \& Palincsa, A. (1991). Motivating Project-Based Learning: Sustaining the Doing, Supporting the Learning. Educational Psychologist, 26(3\&4), 369-398.

Carey, J. W. (1989). Communication as Culture: Essays on Media and Society. New York: Routledge.

Dewey, J. (1927). The Public and its Problems. New York: Holt.

Engeström, Y. (1987). Learning by Expanding: an Activity Theoretical Approach to Developmental Research. Helsinki: Orienta-Konsultit.

Gomes, A., Manuel, A., Rodrigues, A., Borga, C., Andringa, D., de Abreu, D., Ferreira, L. (2011). Ser Jornalista em Portugal - Perfis sociológicos. (J. Rebelo, Ed.) (1. ${ }^{\mathrm{a}}$ ed.). Lisboa: Gradiva.

Gordon, R. (2003). The meanings and implications of convergence. In K. Kawamoto (Ed.), Digital Journalism: Emerging Media and Changing Horizons of Journalism. Lanham: Rowman \& Littlefield. 
Graça, S. M. (2007). Os Jornalistas Portugueses: dos problemas da inserção aos novos dilemas profissionais. Coimbra: Minerva Editora.

Jenkins, H. (2006). Convergence culture: where old and new media collide. New York: New York University Press.

Kaptelinin, V., \& Nardi, B. A. (2006). Acting with Technology: Activity Theory and Interaction Design. Cambridge, MA: MIT Press.

Lektorsky, V. A. (2009). Mediation as a Means of Collective Activity. In A. Sannino, H. Daniels, \& K. D. Gutiérrez (Eds.), Learning and Expanding with Activity Theory (pp. 75-87). Cambridge: Cambridge University Press.

Matos, J. N., Baptista, C., Subtil, F. (2017). A crise do jornalismo em Portugal. Porto: Deriva e Outro Modo, Le Monde Diplomatique.

McLuhan, M. (1962). The Gutenberg galaxy: the making of typographic man. Toronto: University of Toronto Press.

McLuhan, M. (1971). Convocation Address. The University of Alberta. McLuhan Studies, Issue 5.

McLuhan, M. (2003). Understanding Me: Lectures and Interviews. Toronto: McClelland \& Stewart.

McLuhan, M., Hutchon, K., \& McLuhan, E. (1977). City as classroom: Understanding language and media. Book Society of Canada.

McLuhan, M., \& McLuhan, E. (1988). The Laws of Media: the new science. Toronto: University of Toronto Press.

Mensing, D. (2010). Rethinking [Again] the Future Of Journalism Education. Journalism Studies, 11(4), 511-523.

Nardi, B. A. (1996). Activity Theory and Human-Computer Interaction. In B. A. Nardi (Ed.), Context and Consciousness: Activity Theory and Human-Computer Interaction (pp. 48). MIT Press.

Obercom. (2017). Profissão Jornalista: Condições Laborais, Formação e Constrangimentos. Lisboa: Publicações OberCom, ISSN 2182-6722.

Patrão, C. (2006). Projeto E-Comunicar. In Actas do VII Colóquio sobre Questões Curriculares (III Colóquio Luso-Brasileiro). Braga: Centro de Investigação em Educação da Universidade do Minho.

Patrão, C., \& Figueiredo, A. D. (2011). Educating the new generation journalist: from Moodle to Facebook. Presented at the International Symposium on Online Journalism, University of Austin, TX.

A social web based pedagogical strategy for teaching journalism in higher education. Carla Patrão y António 
Patrão, C., \& Soeiro, D. (2009a). E-aulas na ESEC: muito para além das aulas. Exedra, (2), 79-91.

Patrão, C., \& Soeiro, D. (2009b). O Moodle e a Pedagogia no Ensino Superior: Um casamento ou um divórcio tecnológico? In B. D. Silva, Leandro S. Almeida, Alfonso Barca, \& Manuel Peralbo (Eds.), Actas do X Congresso Internacional Galego-Português de Psicopedagogia (pp. 5881- 5890). Braga: Universidade do Minho.

Patrão, C. (2015). A educação de uma nova geração de jornalistas: Do Moodle ao Facebook. Coimbra, Tese de doutoramento. Disponível em: http://hdl.handle.net/10316/27151.

Pavlik, J. V., \& McIntosh, S. (2018). Converging Media (6 edition). New York: Oxford University Press.

Quinn, S. (2009). Convergence Journalism: The Fundamentals of Multimedia Reporting. New York: Peter Lang Publishing Inc.

Rebelo, J. (2011). Apresentação. In Ser Jornalista em Portugal - Perfis sociológicos (1st ed., pp. 11-37). Lisboa: Gradiva.

Scalon, E., \& Issroff, K. (2005). Activity Theory and Higher Education: evaluating learning technologies. Journal of Computer Assisted Learning, 21 (6), 430-439. Doi:10.1111/j.1365-2729.2005.00153.x. 